\title{
Role of Guava to National Economy of Bangladesh: An Empirical Study
}

\author{
Sayed Mohibul Hossen
}

Senior Lecturer in Statistics, Department of Business Administration, NUB, Bangladesh

\begin{abstract}
Guava, which is a very delicious fruit, is rich in vitamin C and contains the appreciable amount of vitamin A too. It is also a good source of pectin -a dietary fiber. Different types of favorite dishes are made from guava such as guava jelly, guava syrup, guava cheese, guava roll, etc. Many countries export these types of foods and earn a lot of foreign money. Although Bangladesh is one of the best producers, there is no industry for preserving this fruit. So, all the production become indeed in consumption.The aim of the research is to know the cultural practices of guava in Bangladesh and how to make sweetened guava dishes which can play a vital role to our economy and to identify the best model that may be used for forecasting purposes. The present study attempts to do a statistical analysis of current guava production and its prospect in Bangladesh by considering the various sources of variations on the time-series data for 23 districts of Bangladesh and over a period of 27 years (1981-82 to 2007-08). The study was considered for whole Bangladesh.
\end{abstract}

Keywords: Guava, Significant, National Economy, Production, Bangladesh

JEL Classification Code: E01; E20

\section{INTRODUCTION}

The long history of guava's use has led modern-day researchers to study guava extracts. Its traditional use for diarrhea, gastroenteritis and other digestive complaints has been validated in numerous clinical studies. A plant drug has even been developed from guava leaves (standardized to its quercetin content) for the treatment of acute diarrhea. Human clinical trials with the drug indicate its effectiveness in treating diarrhea in adults. Guava leaf extracts and fruit juice has also been clinically studied for infantile diarrhea. In a clinical study with 62 infants with infantile rotavirus enteritis, the recovery rate was 3 days $(87.1 \%)$ in those treated with guava, and diarrhea ceased in a shorter time period than controls. It was concluded in the study that guava has "good curative effect on infantile rotavirus enteritis." In a recent study with guinea pigs (in 2003) Brazilian researchers reported that guava leaf extracts have numerous effects on the cardiovascular system which might be beneficial in treating irregular heart beat (arrhythmia). Previous research indicated guava leaf provided antioxidant effects beneficial to the heart, heart protective properties, and improved myocardial function. In two randomized human studies, the 
consumption of guava fruit for 12 weeks was shown to reduce blood pressure by an average 8 points, decrease total cholesterol levels by $9 \%$, decrease triglycerides by almost $8 \%$, and increase "good" HDL cholesterol by $8 \%$. The effects were attributed to the high potassium and soluble fiber content of the fruit (however 1-2 pounds of fruit was consumed daily by the study subjects to obtain these results!). In other animal studies guava leaf extracts have evidenced analgesic, sedative, and central nervous system (CNS) depressant activity, as well as a cough suppressant actions. The fruit or fruit juice has been documented to lower blood sugar levels in normal and diabetic animals and humans. Most of these studies confirm the plant's many uses in tropical herbal medicine systems.(Conde Gracia,E,et al2003)

\section{Scientific classification}

Psidium Guava. L

Kingdom : plantae

Division :magnoliophyta

Class

Sub class :magnoliopsida

Order :rosidae

Family :myrtales

Sub family

Genus :Myrtaceae

Species :myrtoideae :Psidium

Guavas are plants in the myrtle family (Myrtaceae) genus Psidium, which contains about 100 species of tropical shrubs and small trees. Native to Mexico and Central America, northern South Africa, parts of the Caribbean and some parts North Africa. Guava are now cultivated naturalized throughout the tropics and are also grown in some subtropical regions. (Jimmy Wales, 2008)

\section{WorLd-Wide Distribution ANd Production Of GuAVA}

Today, the fruit can be found growing in more than fifty countries throughout the tropics and subtropics, including some of the Mediterranean areas. In Europe guava is grown in Spain, Portugal, Southern France and Israel. In the United States, guava can be found in California, Florida and Hawaii. In its native habitat of central and northern South America. Well in Mexico, Panama, El Salvador, Costarica, Nicaragua, Bolivia and Brazil.The major producers of guava in the world are India, Brazil and Mexico. Other leading countries are South Africa, Jamica, Kenya, Cuba, the USA (Mainly Florida and Hawaii), Egypt, Columbia and the Philipines.(Mathew Montoya)

$\begin{array}{ll}\text { Country } & \begin{array}{l}\text { Amount grown } \\ \text { ( in Metric tons) }\end{array} \\ \text { India } & 200,000 \\ \text { Mexico } & 175,000 \\ \text { Cuba } & 90,714 \\ \text { Egypt } & 34,000 \\ \text { South Africa } & 13,000 \\ \text { Bangladesh } & 146,077\end{array}$

It is palpable from the chart below that the Production of guava in Bangladesh is increasing year to year. From the chart we can say that the maximum and minimum production of guava in India and South Africa respectively. It is also clear that Bangladesh has the $3^{\text {rd }}$ position in the world for its guava production. 


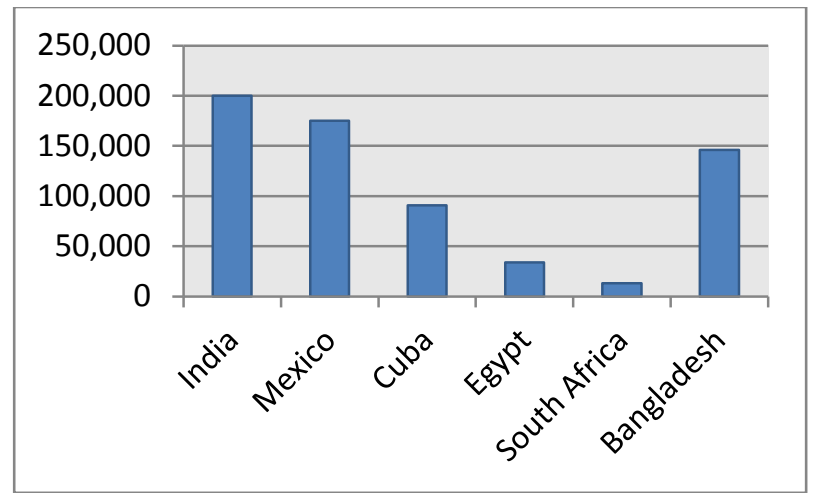

\section{Different kinds of Guava In Bangladesh}

Mainly two types of guava are cultivated in our country commercially.

1. Kazi Peara (guava)

2. Bari Peara

Kazi Peara : Year round high yielding variety fruit weight $445.5 \mathrm{gm}$, shape pear to round length $9.37 \mathrm{~cm}$, breadth $9.66 \mathrm{~cm}$, skin colour yellowish green flesh colour whitish texture crispy taste slightly sour TSS 8.2-13.2\% vitamin c content $202.4 \mathrm{mg} / 100 \mathrm{~g}$ fruit.

Shelf life 7-10 days. Yield $84 \mathrm{~kg} /$ plant. Released from the horticulture research centre Joydebpur, Gazipur.(BARI, 2003)

Bari Peara- 2: Year round high yielding variety fruit weight $240 \mathrm{gm}$ shape roundish length $6.4 \mathrm{~cm}$ breadth $7.4 \mathrm{~cm}$ skin colour greenish yellow flesh colour whitish texture crispy taste sweet TSS $7.8-12.8 \%$. Shelf life 7 days. Yielding $90 \mathrm{~kg} /$ plant. Released from the regional horticulture research station Akbarpur, Moulovibazar.(BARI, 2003)

\section{Total cultivated area of guava in six divisions}

The graphic representation given below, it is observed that the cultivated area of guava in six divisions is increasing year to year. From the year 2004-05 area is considered only fruit bearing garden so the line represents decreasing from 2004-05. The chart also represents that the highest cultivated division is Dhaka and Chittagong.

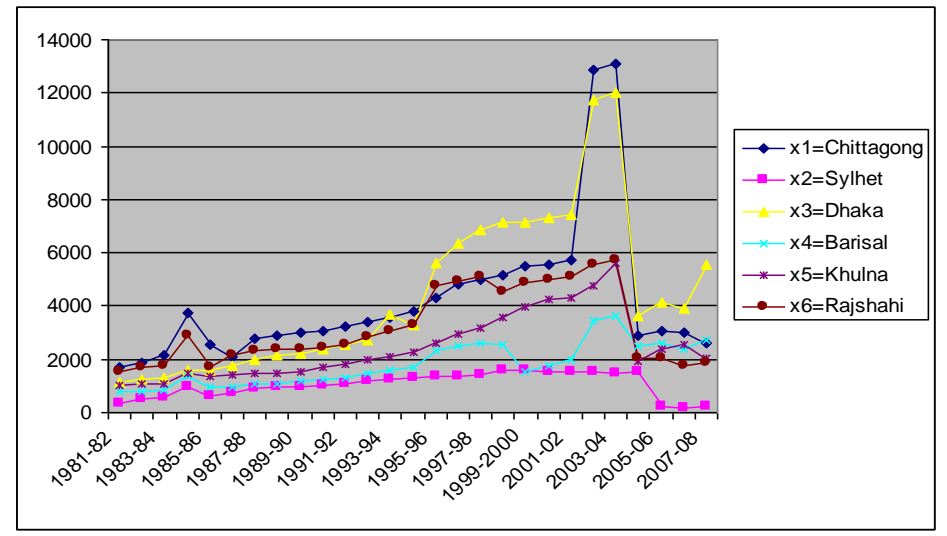

\section{Area wise Production of guava in Bangladesh}


It is observed from the graph below that the area wise production of guava is increasing year to year. The highest increase in the area wise production of guava is in the year 200405 and for the next three years, the areas increase gradually and also the production.

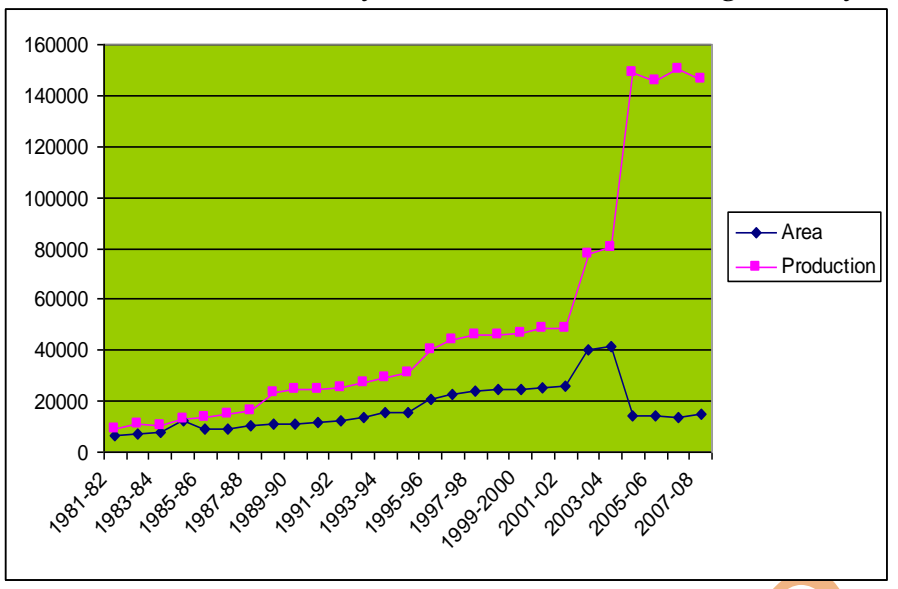

\section{Materials AND Methods}

\section{Regression analysis}

Regression analysis is a branch of statistical theory that is widely used in almost all the scientific disciplines. In economics it is the basic technique for measuring or estimating the relationship among economic variables that constitute the essence of economic theory and economic life. for example, if we know that two variables price ( $x$ ) and demand $(y)$ are closely related we can find out the most probable value of $x$ for a given value of $y$ or the most probable value of $y$ for a given value of $x$. similarly, if we know that the amount of tax and the rise in the price of a commodity are closely related, we can find out the expected price for a certain amount of tax levy. With the help of regression analysis, we are in position to find out the average probable change in one variable given a certain amount of change in another.(Shil \& Nath, 2008)

\section{The Log-Linear model}

Let us consider the following regression model;

$$
Y_{i}=\beta_{1} X_{i}^{\beta 2} e^{u i}
$$

This may be expressed as,

$$
\ln Y_{i}=\ln \beta_{1}+\beta_{2} \ln X_{i}+u_{i}
$$

Where $\ln =$ natural $\log$ (i.e., $\log$ to the base e, and where $e=2.718$ )

If we write as

$$
\ln Y_{i}=\alpha+\beta_{2} \ln X_{i}+u_{i}
$$

Where $\alpha=\ln \beta_{1}$

This model is linear in the parameters $\alpha$ and $\beta_{2}$, linear in the logarithms of the variables $\mathrm{Y}$ and $\mathrm{X}$, and can be estimated by OLS regression. Because of this linearity, such models are called log-log, double-log, or log-linear models. If the assumptions of the classical regression model are fulfilled, the parameters can be estimated by the OLS method by letting 


$$
Y_{i}^{*}=\alpha+\beta_{2} X_{i}^{*}+u_{i}
$$

Where $Y_{i}^{*}=\ln Y_{i}$ and $X_{i}^{*}=\ln X_{i}$. The OLS estimators $\hat{\alpha}$ and $\widehat{\beta}_{2}$, respectively.

\section{Feature of the log-linear model}

Two special features of the log-linear may be noted:

1. One attractive feature of the log-linear model, which has made it popular in applied work, is that the slope coefficient $\beta_{2}$ measures the elasticity of $\mathrm{Y}$ with respect to $X$. which means that the percentage change in $Y$ for a given (small) percentage change in $X$.

2. Another feature of the model is that although $\widehat{\alpha}$ and $\widehat{\beta}_{2}$ are unbiased estimates of $\alpha$ and $\beta_{2}, \beta_{1}$ (the parameter entering the original model) when estimated as $\widehat{\beta}_{1}=\operatorname{anti} \log (\widehat{\alpha})$ is itself a biased estimator

\section{RESULTS AND Discussion}

The coefficient of determination $R^{2}$ of the equation is 0.55 , which indicates that $55 \%$ of the total variation Of the Dependent variable has been explained by the Independent variable. It can be said that the goodness of fit is good on the average. This result also suggests that, if the cultivated area increases thousand hector then production/supply will increases on the average by 1.15 thousand metric ton.

\begin{tabular}{|r|r|r|r|r|}
\hline R & R Square & Adjusted R S quare & \multicolumn{1}{|c|}{$\begin{array}{c}\text { Etd. Error of the } \\
\text { Estimate }\end{array}$} & Durbin-Wats on \\
\hline $.553=$ & .305 & .275 & .67517 & .284 \\
\hline
\end{tabular}

a. Predictors: (Constant), area

b. Dependent Variable: production

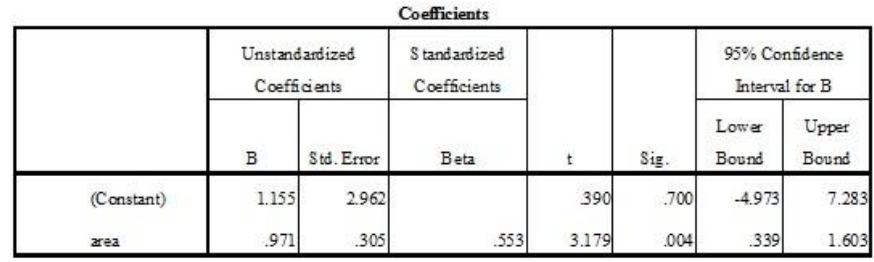

a. Dependent Variable: production

\begin{tabular}{|l|r|r|r|r|r|}
\hline & ANOVA \\
\hline Sum of Squares & df & Mean S quare & F & S ig. \\
\hline Regression & 4.607 & 1 & 4.607 & 10.107 & $.004^{=}$ \\
Residual & 10.485 & 23 & .456 & & \\
Total & 15.092 & 24 & & & \\
\hline
\end{tabular}

a. Predictors: (Constant), area

b. Dependent Variable: prodvetion

Finally we have concluded that the production of guava in Bangladesh is increasing day by day. The soil and weather condition of our country is excellent for guava cultivation. 
From this study it is clear that the production is responsive to its area. That is, as expected area rises, the corresponding supply rises. This indicates that there is a direct relationship between expected production of guava and the cultivated area

Favorite guava Dishes \& medical uses:

Guava is very delicious fruit. Many favorite and tasty items are made from guava and these products are imported by many country. Such as, guava jelly, guava syrup, guava cheese, guava roll, etc. (K.Y. and M.G. Brown, 1980)

Preparation of guava jelly

$\begin{array}{ll}\text { Item } & \text { Quantity } \\ \text { Clear fruit juice } & 1 \text { liter } \\ \text { Sugar } & 1 \mathrm{~kg} \\ \text { Citric acid } & 10 \mathrm{gm} \\ \text { Sodium benzoate } & 1 \mathrm{gm} \\ \text { Color/flavor } & \text { To taste }\end{array}$

\section{Procedure}

1. Extract juice from fruit of good quantity and keep for a day or two for the co are particles to settle down.

2. Filter/siphon clear juice.

3. Mix juice and sugar in a kettle and start boiling with continuous string.

4. When total soluble solid reaches $68^{*}$ c stop boiling.

5. Add Sodium Benzoate, CS and flavor according to the formula.

6. Mix thoroughly fill in clean sterilized jars.

7. Cap, cool, wash, label store in a cool and dark place.

Preparation of guava syrup

$\begin{array}{ll}\text { Item } & \text { Quantity } \\ \text { Juice } & 1 \text { liter } \\ \text { Water } & 1 \text { liter } \\ \text { Sugar } & 4 \mathrm{~kg} \\ \text { Citric acid } & 30 \mathrm{gm} \\ \text { Potassium Metabisulphite } & 4 \mathrm{gm}\end{array}$

\section{Procedure}

1. Select healthy white fleshed fruit

2. Wash thoroughly with tap water

3. Sort carefully, discard diseased, wormy and undesirable fruit

4. Cut into pies

5. Beat with about $20 \%$ of water and extract pulp passing it through juices/pulped of muslin cloth

6. Boil sugar and water according to the formula

7. Add pulp (juice) as per formula and stir well

8. Add citric acid and KMS as usual and mix thoroughly

9. Fill in clean, sterilized glass bottles, cap, wash, label and store in a dark, cool place.

Guava cheese

Guava cheese can be prepared from fresh fruit slices or from the puree extract. 


\section{Procedure}

1. To $1 \mathrm{~kg}$ of puree extract

2. Add $1.5 \mathrm{~kg}$ of sugar

3. Add $2.5 \mathrm{~g}$ of butter

4. Heat until thick

5. Add $2 \mathrm{~g}$ citric acid

6. One tb of salt

7. Pour into buttered trays in $0.5 \mathrm{~cm}$ layers.

\section{Guava Roll}

A cookie-like pastry is rolled around sweet guava paste into a loop shape. Guava rolls are only moderately sweet .compared to some other Cuban-style pastries.

Masa Real

Another guava pastry, masa real comes in two forms; both are made with the same dough and filling. One looks like a giant thumbprint cookie, round with a patch of guava in the center. The other is like a very large guava-cookie sand-witch, with the guava filling between two layers of the cookie-like pastry.

\section{Brazo de Gitano}

These jelly roll style cakes, fancifully named "gypsy's arm" (presumably because of their shape) are doused with rum syrup and then filled with custard or guava filling.

Worldwide Ethno-medical uses

\begin{tabular}{|c|c|}
\hline India & $\begin{array}{l}\text { For anorexia, cerebral ailments, child birth, cholera, } \\
\text { convulsions, epilepsy nephritis }\end{array}$ \\
\hline Mexico & $\begin{array}{l}\text { For deafness, diarrhea, itch, scabies, stomachache, swelling, } \\
\text { ulcer, worms }\end{array}$ \\
\hline Haiti & $\begin{array}{l}\text { For dysentery, diarrhea, epilepsy, itch, piles, scabies, skin sores, } \\
\text { sore throat, stomachache, wounds }\end{array}$ \\
\hline Amazonia & $\begin{array}{l}\text { For diarrhea, dysentery, menstrual disorder, stomachache, } \\
\text { vertigo }\end{array}$ \\
\hline Brazil & $\begin{array}{l}\text { For anorexia, cholera, diarrhea, digestive problems, dysentery, } \\
\text { gastric insufficiency, inflamed mucous membranes laryngitis, } \\
\text { mouth (swelling), ski problems, sore throat, ulcers, vaginal } \\
\text { discharge }\end{array}$ \\
\hline Cuba & For colds, dysentery, dyspepsia \\
\hline Malaya & For dermatitis, diarrhea, epilepsy, hysteria, menstrual disorders \\
\hline Ghana & Coughs, diarrhea, dysentery, toothache \\
\hline Philippines & For sores, wounds and as an astringent \\
\hline Trinidad & Bacterial infections, blood cleansing, diarrhea, dysentery \\
\hline Else where & $\begin{array}{l}\text { For anorexia, aches, bacterial, infections, boils, bowel disorders, } \\
\text { bronchitis, catarrh, cholera, chorea, colds, colic, coughs, } \\
\text { diarrhea, dysentery, edema, fever, itch jaundice, menstrual } \\
\text { problems, nausea, scabies, sore throat, spasms, sprains, stomach } \\
\text { problems, swelling, tonic, toothache, ulcers, wounds and as an } \\
\text { antiseptic and astringent. }\end{array}$ \\
\hline
\end{tabular}

(Leslie Taylor, 2005) 


\section{POLICY IMPLICATIONS}

While the production of guava is increasing and it has a great opportunity to play vital role in our economy but there is no technique has been taken for its preservation. So, all the production become indeed in consumption. To improve our economy government needs to take some necessary steps.

1. Since the production of guava is responsive to area, by increasing cultivated area of guava it is possible to raise its production.

2. By preserving and manufacturing different guava dishes we can fulfill our food requirement (nutrition) all the year round and can improve our economy by importing its sweetened dishes.

\section{REFERENCES}

[1] BADC: Directorate of agriculture marketing, Bangladesh Agriculture Develop Council, Khamar Bari, Farm-gate, Dhaka.

[2] BARI,(2003) Joydebpur, Gazipur-1701, Bangladesh

[3] Conde Garcia, E. A., et al. "Inotropic effects of extracts of Psidium guajava L. (guava) leaves on the guinea pig atrium." Braz. J. of Med. E Biol. Res. 2003; 36: 661-668.

[4] Jimmy Wales, Wikipedia Founder.Wikipedia ${ }^{\circledR}$ is a registered trademark of the Wikimedia Foundation, Inc., a U.S. registered 501(c)(3)tax-deductiblenonprofitcharity.

[5] K.Y. and M. G. Brown [1980], "economic effectiveness of brand advertising programmes for u.s.orange juice in the European market. An statistical analysis".journal of agricultural economics, 37,pp.385-395.

[6] Leslie Taylor," The Healing Power of Rainforest Herbs"

[7] montymex@ocf.berkeley.edu

[8] Shil \& Nath (2008): "An introduction to the theory of STATISTICS" 